\title{
A BIRD LIST FOR THOMPSON, MANITOBA
}

\section{by Joseph W. Johnson, Black Diamond, Alberta}

EDITOR'S NOTE: Joe Johnson, formerly of Nova Scotia, has been an active birder for a number of years. In recent years he contributed more than 800 nest records to the Maritimes Nest Records Scheme. As a result of a nine-month stay at Thompson he has made a worthy contribution to the knowledge of birds in this still remote part of Manitoba.

Although Thompson is the third largest city in Manitoba (second only to Winnipeg and Brandon), with a population of more than 70,000 , no previous list of birds for the area has come to our attention. Thompson, which is more than 400 miles north of Winnipeg and within the Nelson River drainage system, lies within a vast rezion that is poorly known ornithologically.

The nearest points for which published records are available are Thicket Portage, 30 miles south, and Pikwitonei, 30 miles eastsoutheast. Observations were made at Thicket Portage by a party led by $P$. A. Taverner in August 1936 (W. E. Godfrey, Nat'l Mus. Can. Bull. No. 128, pp. 1-52, 1953). H. W. R. Copland in 1949 and again in 1950 , accompanied ry G. J. Sm:th, recorded specirs in the Pikwitonei area for brief periods in the summer season (Nat. Hist. Soc. Manitoba Newsletter, 1963 , Nos. $3 \& 4$ ). Twenty-one of 88 species reported at Thicket Portage and 13 species reported at Pikwitonei were unrecorded at Thompson. However, 38 additional species were observed at Thompson by Johnson. Two other species were recorded at Thompson by $T$. Lindsey. The combined lists include about 130 species.

Some of Johnson's records are of special interest in providing or suggesting range extensions, and verifying data; see, for example, Red-breasted Nuthatch, Magnolia Warbler, Ovenbird, Red-winged Blackbird, Purple Finch, Pine Siskin and Vesper Sparrow. Perhaps his most interesting observation is that of a large flock of Long-tailed Jaegers evidently blown inland from the Churchill region hy an unusual torm. This is an unprecedented inland record for this species.

All the observations that I am going to report in this paper, unless otherwise noted, were made within three miles of the centre of Thompson. The city itself comprises only a small part of the six-mile-diameter circle which constituted the area of my study. Observations were made between November 13, 1968, when I arrived in the city, and August 10, 1969, when I left. The ares is generally quite flat and forested. There is one small lake which is essentially dead owing to chemical pollution, and a fairly large river. About one-third of the area is settled or has been cleared. Muskeg forest takes up less of the area than upland forest. There is very little open muskeg. Black spruce is by far the commonest tree species, aspen and jack pine being next. Several patches of black spruce remain within the city. The inadvertent creation of several ponds in one area provided good habitat for a number of species, this being the only place where I found Redwings, Soras, several duck species and most of the Grackles. In contrast to many lakes in northern Manitoba there was no large growth forest around the lake and no new species were found there.

I saw or heard at least 104 species in the area, 103 of which were definitely identified. I believe at least 50 species bred there in 1969 . With 17 species, the evidence was conclusivenests with eggs or young, or young broods; with the rest I went mostly by degree of abundance and singing during the nesting season. Chipping Sparrows were the commonest nesters. I saw a number of young with parents in July and August, more than in the case of any other species. The same goes for the amount of singing heard, and the number of old nests found, which totalled at least a dozen. They were found chiefly in the coniferous forest, only coming into the city where there were patches of conifers. Probably only five or six species nested within the city, including Chippies. The nesting season was quite short. I saw no evidence of second nestings of any species.

Three snowstorms, associated with unseasonably cold weather and north winds on May 18, May 27 and 28, and June 11 and 12 , strange as it may seem, appeared to bring in migrants from the south. As soon as the weather cleared after each storm, and before the wind had shifted, or much warming had taken place, numbers of migrants were evident, especially of species which had not yet appeared in the area, including some close to the 


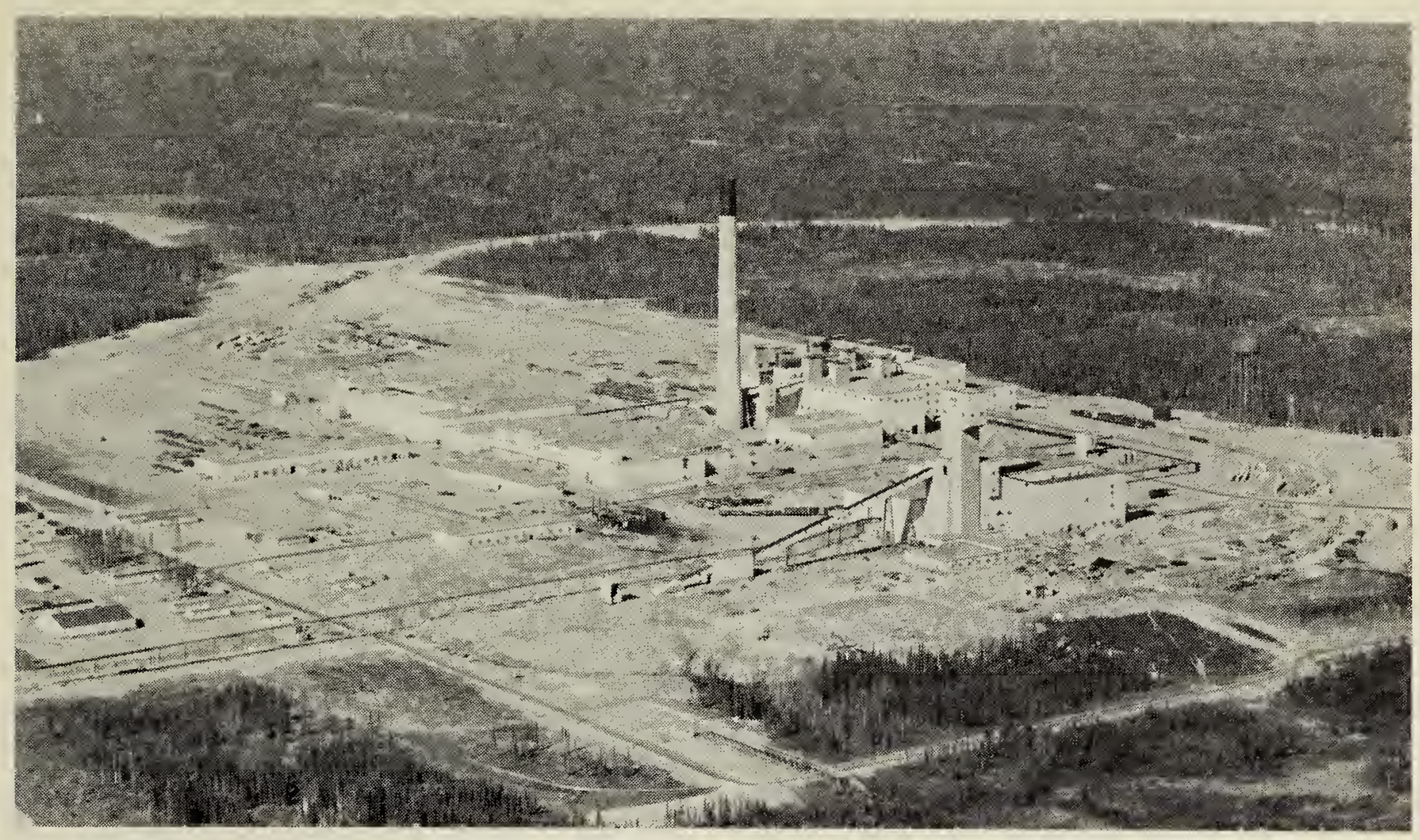

Smelter at Thompson

Manitoba Government Photo

northern known limit of their breeding range. The June storm, with winds stronger than the other two, also apparently brought birds that nest farther north. This storm probably accounted for the Fox Sparrows, White-crowned Sparrow, Harris' Sparrows, Long-tailed Jaegers, Roughlegged Hawk, Water Pipits, the three species of migrating shorebirds, and some of the Horned Larks and Lapland Longspurs that appeared on June 13 and later. It is very unusual, for example, to see Long-tailed Jaegers so far south and inland. Perhaps Purple Finches and Solitary Vireos would have bred in the area, but were wiped out in the long, fierce June storm. I found four dead small birds of three species after the May 27-28 storm. The six inches of snow deposited by the June storm took several days to melt and must have had a disastrous effect on duck nests.

I was surprised at the absence or near-absence of Common Loons, Canada Geese, Spruce Grouse and Palm Warblers. Heavy shooting pressure in the spring and autumn may have accounted for the apparent absence of Spruce Grouse and the scarcity of
Ruffed Grouse. There was little or no shooting during the nesting season, so probably the local duck breeding population was not much affected by gunners.

\section{Species List}

COMMON LOON. One each on July 12 and 31.

MALLARD. Fairly common in May and June, uncommon in July. First seen for certain April 25 (saw the first ducks on April 24, unidentified, probably Mallards); saw one brood.

GREEN-WINGED TEAL. Common. First seen April 25; found one occupied nest, May 30, incubating, and one brood; flock of 30 on August 4.

BLUE-WINGED TEAL. Seen three or four times in June and end of May, starting May 29, up to three at a time.

AMERICAN W IDGEON. Fairly common. First seen May 29; probably breeding.

SHOVELER. Rather uncommon. First seen May 31, last seen June 30 (a pair); may have bred sparingly.

RING-NECKED DUCK. Rather uncommon. First seen May 29; probably breeding. 
(LESSER SCAUP?). Three ducks seen in poor light on April 25 seemed to be of this species.

COMMON GOLDENEYE. Rather uncommon. First seen May 21; found one occupied nest, June 14, incubating.

BUFFLEHEAD. A pair on May 6, two females each on June 5 and July 14.

(HOODED MERGANSER?). Saw in the distance what appeared to be a male of this species on June 24 .

COMMON MERGANSER. One each on May 8, June 26, July 12.

GOSHAWK. One on January 19.

RED-TAILED HAWK. Two on May 6 , one on May 8.

ROUGH-LEGGED HAWK. One on June 13.

MARSH HAWK. One on June 15.

(PIGEON HAWK?) One may have been seen twice in June and July, but identity not certain.

SPARROW HAWK. Fairly common. First seen April 25; almost certainly breeding; saw a pair mating.

S.PRUCE GROUSE. T. Lindsey reported four seen, January 1, 1964 (Nat. Hist. Soc. Manitoba, Newsletter 1964 No. 1, p. 12) (Ed.).

RUFFED GROUSE. Uncommon. Present bath winter and summer; saw one brood.

WILLOW PTARMIGAN. Saw one December 20; in spring found wings and feathers at several places and one intact dead one. T. Lindsey saw this species on six occasions in the Thompson region during the winter of 1965 (Nat. Hist. Soc. Manitoba Newsletter 1965, No. 1, p. 3) (Ed.).

SHARP-TAILED GROUSE. Four on April 20.

SORA. Fairly common in one area. First heard May 17; only seen once; very likely breeding.

SEMIPALMATED PLOVER. Two on May 31, one each on June 13 and 14.

KILLDEER. Common. First seen April 20; very likely breeding.

COMMON SNIPE. Fairly common. First noted (heard) April 30; found one occupied nest, June 30 , incubating.

SPOTTED SANDPIPER. Common.
First seen May 29; found one occupied nest, July 6 , incubating.

SOLITARY SANDPIPER. Fairly common. First seen May 17; very likely breeding.

GREATER YELLOWLEGS. Heard one on May 3, saw one on May 17.

LESSER YELLOWLEGS. Uncommon in May, June, July. First noted for certain May 29, but I heard what I believe was one of this species on May 12, and saw and heard what I believe was one on May 17; probably bred sparingly.

LEAST SANDPIPER. Rather uncommon from May 31 till June 13; five also seen on July 14.

SEMIPALMATED SANDPIPER. One on June 13, three on June 14.

LONG-TAILED JAEGER. A flock on and near Burntwood River June 13 to June 27, largest number seen: 27 to 29 on June 14; very long central tail feathers and all other marks distinguishing the species from Parasitic Jaeger clearly noted. Activities included swimming in loose groups, resting on land in loose groups up to one-tenth mile from water, flying, and one day, apparently, flycatching. They stayed in a rather small area generally, but on four occasions one or two were seen about a mile away and some distance from the Burntwood River at Thompson flying over woods and roads.

HERRING GULL. Abundant in May and June, uncommon in July. First seen April 20; apparently didn't breed close to Thompson.

RING-BILLED GULL. T. Lindsey recorded 300 on April 30, 1964 (Nat. His.t. Soc. Manitoba, Newsletter 1964, No. 2, p. 23) (Ed.).

COMMON TERN. Many at Paint Lake, 20 miles south of Thompson, on July 29, apparently nesting. Two unidentified Sterna terns at Thompson, June 16.

ROCK DOVE. Two on June 28.

MOURNING DOVE. One on May 17.

B L A CK - B ILLED CUCKOO. H. Hosford heard one calling on June 15, 1966 in deciduous woods on the Burnt- 
wood River just north of Thompson (pers. comm., 1969, Ed.).

GREAT HORNED OWL. Heard two on March 23, saw and heard one May 21, saw one July 31 ; probably breeding.

GREAT GRAY OWL. T. Lindsey recorded two in late December, 1965 (H. Mossop, "Chickadee Notes" No. 574, Wpg. Free Press, January 15, 1966) (Ed.).

BOREAL OWL. Saw one on July 28 , perhaps a juvenile.

COMMON NIGHTHAWK. Common. First seen June 3; very likely breeding.

BELTED KINGFISHER. Rather uncommon. First noted (heard) April 29 ; found one new nest tunnel being excavated in June, earth around it fell away before it was completed.

YELLOW - SHAFTED FLICKER. Rather uncommon. First noted (heard) April 27; very likely breeding.

Y E LL O W - B E L L I E D S A P SUCKER. Uncommon. First noted (heard) on May 30; May 31, drilling nest cavity (later saw young).

HAIRY WOODPECKER. One each on February 8, March 25.

BLACK-BACKED THREE-TOED WOODPECKER. Saw a female close to a newly excavated woodpecker nest cavity on June 30, no sign of life at nest on later visits; also saw one each, June 13, July 26.

N O R T H ER N THREE - TOED WOODPECKER. One each on May 12 , August 4.

EASTERN KINGBIRD. Heard one on June 27.

EASTERN PHOEBE. Saw one May 6, heard one June 13.

Y E L L O W - B E L L I E D FLYCATCHER. Heard one on June 7.

TRAILL'S FLYCATCHER. Rather uncommon. First seen June 7; probably breeding.

LEAST FLYCATCHER. Uncommon. First noted June 1 (heard); found one occupied nest, June 27, laying.

OLIVE - SIDED FLYCATCHER. Heard one on June 7.

HORNED LARK. Common from
May 14, when first seen, till June 17, when last seen. Strictly a transient.

TREE SWALLOW. Common. First seen May 1, saw a number of them near two bird boxes in July; very likely breeding.

BANK SWALLOW. Uncommon. First seen May 31; apparently doesn't breed close to Thompson.

BARN SWALLOW. Rather uncommon. First seen June 13; probably breeding.

CLIFF SWALLOW. Fairly common. First seen June 13. Found nine occupied nests (all separate except for two stuck together) on houses in one area of the city, all with large young, late July and early August. (Large flock of all four species of swallows, inainly Tree and Bank, on June 13, no doubt migrating.)

GRAY JAY. Uncommon from February till August; not seen before February; one carrying nesting material on April 6.

BLACK BILLED MAGPIE. T. Lindsey reported two in late December 1964 (Nat. Hist. Soc. Manitoba Newsletter Supplement, Christmas Bird Count 1964). The species was present at the Thompson garbage dump until February 13, 1965, when five were noted by him (Nat. Hist. Soc. Manitoba Newsletter 1965, No. 1, p. 4) (Ed.).

COMMON RAVEN. Abundant in winter, common in spring and summer; found one occupied nest, June 3, with feathered young.

COMMON CROW. Common. First seen April 12; found one occupied nest, June 1, incubating.

BLACK - CAPPED CHICKADEE. Two on April 6; uncommon from late May till early July; never heard whistled "phoebe" call.

BOREAL CHICKADEE. Uncommon in winter; not noted in April and most of May; rather uncommon May 23 to August.

RED - BREASTED NUTHATCH. Heard one approximately three times in June and late May, starting May 30.

BROWN CREEPER. One May 12. 
AMERICAN ROBIN. Fairly common. First seen April 24; found two occupied nests: one June 19 being built; one July 23 with feathered young.

HERMIT THRUSH. Rather uncommon. First seen May 23; probably breeding.

SWAINSON'S THRUSH. Rather uncommon. First seen May 29; a wave of migrants passed through at end of May and beginning of June; probably breeding.

GOLDEN - CROWNED KINGLET. Uncommon in July, first seen June 30; perhaps bred sparingly.

RUBY - CROWNED K I N G L E T. Common. First noted (heard) April 30 ; very likely breeding.

WATER PIPIT. One or two on May 30 (I believe I heard a few during the week or two before that also), one on May 31, small flock on June 13. 26.

CEDAR WAXWING. Two on July

NORTHERN SHRIKE. One on April 30.

COMMON STARLING. Seen three or four times: two on May 6, two or three on May 31, flock of approximately 12 on July 2.

SOLITARY VIREO. Heard singing approximately four times (seen also) starting May 31, ending June 9 -no more after bad snowstorm of June 11 and 12.

RED-EYED VIREO. Rather uncommon. Singing from late June onwards; first noted (heard) June 27; very likely breeding.

TENNESSEE WARBLER. Rather uncommon. First seen June 7; very likely breeding.

ORANGE-CROWNED WARBLER. Rather uncommon. First seen June 1; very likely breeding.

YELLOW WARBLER. Fairly common till mid-July, scarce or absent thereafter; first seen June 5; found two occupied nests: one June 27, incubating, one July 1, laying.

MAGNOLIA WARBLER. Rather uncommon. First seen June 1; heard singing a number of times; probably breeding.

MYRTLE WARBLER. Common. First seen May 17; female carrying feather and scolding on June 7 ; very likely breeding.

BLACKPOLL WARBLER. One on May 30, four on June 13; apparently didn't breed in the vicinity of Thompson.

OVENBIRD. Uncommon. First seen May 31; heard singing at one spot several times and twice at another spot; very likely bred sparingly.

NORTHERN WATERTHRUSH. Rather uncommon. First seen May 29; very likely breeding.

WILSON'S WARBLER. Uncommon. First seen June 7 ; perhaps bred sparingly.

HOUSE SPARROW. Small numbers (less than 10) in one area of the city, both winter and summer (perhaps only two in winter-numbers appeared to increase in April); probably nested in one or two buildings.

RED-WINGED B L A C K B I R D. Common in one marshy area with ponds; almost certainly breeding, once saw a female scolding frenziedly one of two yards from what appeared to be a Redwing nest (inaccessible). First seen April 30.

RUSTY BLACKBIRD. Three or four on April 25, two on May 29.

COMMON GRACKLE. Very common in one marshy area with ponds. First seen for certain April 25; very likely breeding.

(Unidentified blackbirds, presumably of this or the preceding species, heard on April 20, small flock seen April 21, flock of approximately 100 heard and glimpsed on April 25.)

PURPLE FINCH. Heard a male singing two or three times (also seen). First noted (heard) May 30; none noted after bad snowstorm of June 11 and 12.

HOARY REDPOLL. About five on March 17, two on March 23, two on May 29.

COMMON REDPOLL. Unidentified redpolls were rather uncommmon throughout the winter and spring, 
last seen May 31; presumably the majority were of this species, but only definitely identified one on February 23, approximately 10 on March 6 . Generally redpolls were seen flying too far away for identification, or were just heard.

PINE SISKIN. Fairly common. First noted (heard) June 13; probably breeding.

RED CROSSBILL. Flock of approximately 30 and another (or some of same?) of 15 or more on August 4.

WHITE - WINGED CROSSBILL. Flock of approximately 30 on July 25 ; heard a few on July 23.

SAVANNAH SPARROW. Rather uncommon. First seen May 27, very likely breeding.

VESPER SPARROW. Found one occupied nest, June 27, apparently just finished laying; never saw any adults very far from this nest and never more than one at a time.

SLATE-COLORED JUNCO. Fairly common. First seen April 21; found two occupied nests: one June 24, one July 5 , both incubating.

TREE SPARROW. Common from April 25, when first seen, till May 6, when last seen.

CHIPPING SPARROW. Very common. First seen May 14; found two occupied nests: one July 7, laying, one July 21, incubating.

(Glimpsed a few unidentified Spizella sparrows between May 6 and 14.)
H A R R I S' SPARROW. Passed through in abundance for a week, starting May 19. First seen May 14, last seen June 1, except for a few on June 13.

WHITE - CROWNED SPARROW. Passed through fairly commonly from May 19, when first seen, till May 29, or 30 , when last seen (also one heard on June 13) ; strictly a transient.

WHITE-THROATED SPARROW. Fairly common. First seen May 15. Very likely breeding.

FOX SPARROW. First seen May 19; a wave passed through on May 29 ; last noted May 31, except for four on June 13. Strictly a transient.

LINCOLN'S SPARROW. Very common wherever the habitat was right. First seen May 29; very likely breeding.

SWAMP SPARROW. Common wherever the habitat was right. First noted May 31 (heard); (never seen, just heard) ; very likely breeding.

SONG SPARROW. Rather uncommon. First seen May 6; found one occupied nest, July 3 , incubating.

LAPLAND LONGSPUR. Passed through in abundance in May and June. First seen for certain May 20, last seen June 20 (large flock); (on May 15 saw large flock of birds that were probably Longspurs).

SNOW BUNTING. A number of flocks from last week in April till June 1. First seen April 2, last seen June 3.

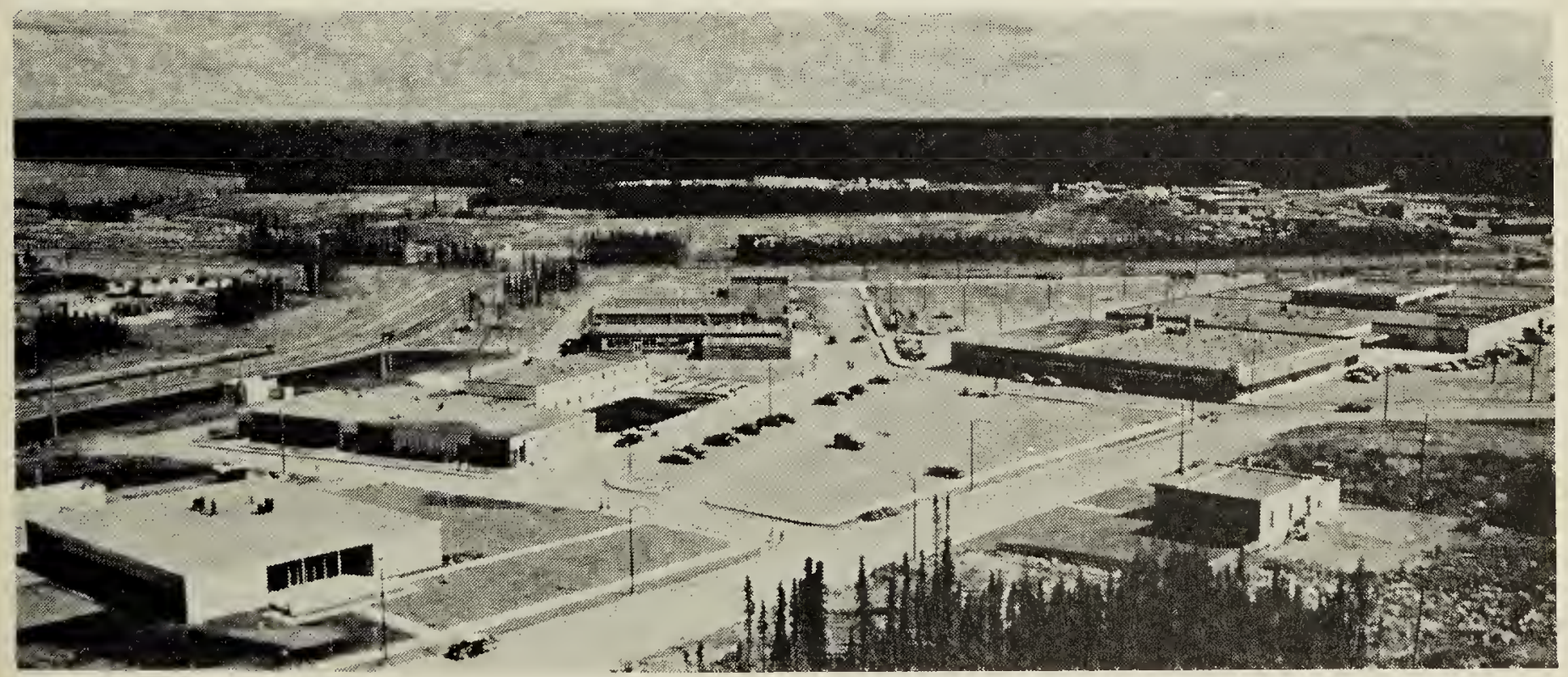

Thompson, Manitoba

courtesy Public Information Branch

March, 1970 